\title{
UTILISATION DE NOUVEAUX TYPES DE CÉRÉALES DANS L'ALIMENTATION DU PORC EN CROISSANCE-FINITION : AVOINE NUE, MAİs « OPAQUE 2 »
}

\author{
Y. HENRY et D. BOURDON \\ Station de Recherches sur l'Élevage des Porcs, \\ Centre national de Recherches zootechniques, I. N.R. A., \\ 78 - Jouy-en-Josas
}

\section{RÉSUMÉ}

Grâce à sa teneur élevée en matières azotées ( 17 p. Ioo de la matière sèche) et à la richesse de ces dernières en lysine (4,35 $\mathrm{g}$ pour $16 \mathrm{~g}$ d'azote), comparativement aux autres céréales, l'avoine nue constitue un aliment de choix pour le Porc. Son introduction dans la ration de finition (entre 50 et roo $\mathrm{kg}$ de poids vif) a permis de réaliser une économie importante de tourteau de soja complémentaire, dont le taux est abaissé à 4 p. Ioo, contre 8 à 12 p. 100 pour les régimes à base d'orge, de blé ou de maïs. En association avec ıo p. Ioo de farine de luzerne déshydratée, l'avoine nue seule suffit pour satisfaire les besoins en azote et en acides aminés, sans addition de lysine supplémentaire. L'indice de consommation est cependant légèrement détérioré, en raison d'un effet dépressif des constituants cellulosiques de la farine de luzerne sur la valeur énergétique du régime. Il en est de même à la suite de l'incorporation de son de blé dans la ration.

De la même façon, la réduction de l'apport de protéines complémentaires est rendue possible par l'incorporation de maïs hybride "Opaque 2 " dans la ration du porc en croissance. Les résultats de bilan azoté sur porc et de croissance sur rat nous autorisent à conclure dans ce sens. Des essais complémentaires sont néanmoins nécessaires pour confirmer ces premières observations et chiffrer, d'une manière précise, l'économie de soja qui pourrait résulter de l'apport supplémentaire de lysine par le maïs «Opaque 2 ».

\section{SUMMARY}

\section{UTIIIZATION OF NEW TYPE CEREALS IN THE FEEDING OF GROWING- FINISHING PIGS : NAKED OATS, " OPAQUE 2 " MAIZE}

According to its high protein content (I 7 P. Ioo dry matter) and to the high level of lysine in these protein $(4,35 \mathrm{~g}$ per $\mathrm{kg} \mathrm{N})$ as compared to the other cereals, the naked oats is a valuable feed for the pig. When it is introduced in a finishing diet (between 50 and roo $\mathrm{kg}$ liveweight), the level of protein supplement, in the form of soybean oil meal, is slowed down to 4 p. roo, against 8 to I 2 p. Ioo for diets based on barley, wheat or maize. When it is fed with Io p. Ioo dehydrated alfalfa meal, the naked oats alone is enough to meet the protein and essertial aminoacid requirements, without supplementary lysine. However, the food conversion ratio is slightly higher, according to a depressive effect of cellulosic substances of dehydrated alfalfa meal on the energy value of the diet. The same effect occurs after including wheat bran in the diet. 
The high lysine " opaque 2 " maize has the same sparing effect on the supplementary protein of the growing pig diet. This was shown by the results obtained through nitrogen balance trials on pigs and growth tests on rats. Further investigations are necessary, however, in order to check these first observations and carry an accurate determination of the amount of complementary soybean oil meal which could be spared by the supplementary lysine of " opaque 2 " maize.

\title{
E. - Adjuvants et antibiotiques
}

Feed additives

\section{COMPARAISON DE L'EFFICACITÉ DE DIVERSES SUBSTANCES AJOUTÉ Dans LES RATIONS DE SEVRAgE DU PORCELET}

\author{
A. AUMAITRE et A. RÉRAT \\ Station de Recherches sur l'Elevage des Porcs, \\ Centre national de Recherches zootechniques, I. N.R.A., \\ 78 - Jouy-en-Josas

\section{RÉSUMÉ,}

324 porcelets sevrés à 5 semaines ont été utilisés au cours de deux expériences pour comparer l'effet de l'introduction de deux substances médicamenteuses (acide acétyl salicylique et salicylate de sodium) ainsi que de 5 antibiotiques dans les aliments des animaux. Le tableau I résume le dispositif expérimental.

Les principaux résultats montrent que l'acide acétyl salicylique incorporé à 500 p.p.m. améliore la croissance, la quantité d'aliment consommée et l'efficacité alimentaire en même temps que l'état sanitaire.

L'antibiosupplémentation à ıoo p.p.m. se traduit par une augmentation spectaculaire des performances des animaux soumis à un stress de changement de porcherie effectué vers II kg ( 5 jours après un sevrage précoce). Cette amélioration est due à la fois (ou associée) à une augmentation de la quantité d'aliment consommée et à une augmentation de l'efficacité alimentaire conjuguées. L'effet de l'antibiosupplémentation sur la mortalité des porcelets est également notable, alors que celui sur la diminution de la morbidité est réel mais plus difficile à estimer.

\section{SUMMARY}

\section{COMPARISON BETWEEN THE EFFICIENCY OF DIFFERENT SUBSTANCES ADDED TO THE WEANING RATIONS OF PIGLETS}

324 piglets weaned at 5 weeks were used during 2 experiments to compare the effect of two drugs (acetyl salicylic acid and sodium salicylate) and 5 antibiotics added to the food rations. Table I shows the experimental schedule. 